\title{
$\mathrm{D} 2 \mathrm{D}$ 통신 시스템을 위한 \\ $\mathrm{CAZAC}$ 시퀀스 기반 링크 스케줄링 기법
}

\author{
강 위 필*, 황 원 준 ${ }^{*}$ 최 형 진
}

\section{Link Scheduling Method Based on CAZAC Sequence for Device-to-Device Communication}

\author{
Wipil Kang*, Won-Jun Hwang ${ }^{*}$, Hyung-Jin Choi ${ }^{*}$
}

요 약

대표적인 D2D (Device-to-Device) 통신 시스템 중 하나인 Qualcomm사의 FlashLinQ 시스템에서는 링크 스케 줄링 과정을 낮은 복잡도로 실현할 수 있도록 하기 위해 단일-톤 (single-tone) 신호를 이용한 우선순위 및 SIR (Signal-to-Interference power Ratio) 기반의 링크 스케줄링 기법을 수행한다. 하지만 다중 경로 채널 환경에서는 주파수 선택적 페이딩의 영향으로 단일-톤 위치에서와 실제 데이터가 전송되는 전체 대역에서의 수신 전력 간 오 차가 발생할 수 있으며, 이는 공평성 측면에서 문제가 될 뿐만 아니라 셀 전체 전송률 상의 손실을 일으킬 수 있 다. 따라서, 본 논문에서는 이러한 문제를 해결하기 위해 CAZAC (Constant Amplitude Zero Auto-Correlation) 시 퀀스의 상관 특성을 이용해 전체 대역에 대한 SIR 에 가까운 값을 획득할 수 있는 링크 스케줄링 기법을 제안한 다. 제안 기법은 전체 대역을 다수의 sub-block 으로 구분하고 각 sub-block 마다 링크의 우선순위에 해당하는 순 환 오프셋 (cyclic offset) 을 적용한 CAZAC 시퀀스를 전 대역에 걸쳐 전송하여, 수신 신호와 참조 신호간의 순환 상호 상관 연산 (cyclic cross-correlation) 을 통해 전체 대역에 대한 SIR 에 근접한 값을 획득할 수 있다.

Key Words : Constant amplitude zero auto-correlation (CAZAC), cyclic correlation, device-to-device (D2D), link scheduling, signal-to-interference power ratio (SIR)

\section{ABSTRACT}

FlashLinQ, one of the typical D2D communication systems developed by Qualcomm, considers a single-tone communication based distributed channel-aware link scheduling method to realize the link scheduling process with low control overheads. However, considering the frequency selective fading effect of practical multi-path channel, the single-tone based SIR estimation causes a critical scheduling error problem because the received single-tone signal has quite different channel gain at each sub-carrier location. In order to overcome this problem, we propose a novel link scheduling method based on CAZAC (Constant Amplitude Zero Auto-Correlation) sequence for D2D communication system. In the proposed method, each link has a unique offset value set for the generation of CAZAC sequences. CAZAC sequences with the cyclic offsets are transmitted using multiple sub-blocks in the entire bandwidth, and then each device can obtain nearly full-band SIR using a good cyclic cross-correlation property of CAZAC sequence.

※ 본 연구는 미래창조과학부 및 정보통신산업진흥원의 대학 IT연구센터 지원사업의 연구결과로 수행되었음 (NIPA-2013-(H0301-13-1005))

- 주저자 : 성균관대학교 정보통신대학 통신시스템 연구실, wipil@ece.skku..ac.kr, 학생회원

* 성균관대학교 정보통신대학 통신시스템 연구실, hms4253@ece.skku..ac.kr, 학생회원, hjchoi@ece.skku..ac.kr, 종신회원 논문번호 : KICS2013-01-054, 접수일자 : 2013년 1월 23일, 최종논문접수일자 : 2013년 3월 26일 


\section{I. 서 론}

최근 스마트폰, 태블릿과 같은 다양한 휴대단말 들의 사용량이 증가함에 따라 새로운 응용 서비스 들을 수용할 수 있는 차세대 무선 네트워크 기술로 서 휴대 단말들 사이의 직접 통신, 즉 $\mathrm{D} 2 \mathrm{D}$ (Device-to-Device) 통신에 대한 관심이 높아지고 있다. D2D 통신은 기지국의 중계 없이 단말간 직 접 링크를 생성하여 통신하는 기술로서, 기존 무선 통신의 급증하는 트래픽으로 인한 부하를 감소시킬 수 있다. 또한, 기존 무선 통신에서의 무선 자원을 효율적으로 재사용할 수 있으므로 무선 통신망 전 체에 대한 전송률 향상을 기대할 수 있으며, 두 개 이상의 단말 상호간 직접 통신을 지원함으로써 새 로운 형태의 P2P (Peer-to-Peer) 서비스를 제공할 수 있다 ${ }^{[1]}$.

이러한 D2D 통신 시스템에서는 링크간 간섭 상 황을 인지하고, 발생 가능한 간섭량을 일정 수준으 로 유지하기 위해 링크 스케줄링 과정이 필수적으 로 수행되어야 한다. D2D 통신은 기본적으로 분산 형 시스템이기 때문에 링크 스케줄링 과정을 통해 각 단말들은 다른 단말들에게 자기 자신으로 인해 발생하는 간섭에 대한 정보를 알려주고, 측정된 간 섭량을 바탕으로 단말 스스로 링크를 계속 유지하 여 통신을 할 것인지, 중단할 것인지를 결정한다. 하지만 이와 같은 분산형 링크 스케줄링 과정에서 모든 단말들이 간섭 정보를 정확히 측정할 수 있도 록 하기 위해서는 높은 오버헤드가 요구된다 ${ }^{[2]}$.

대표적 D2D 통신 시스템인 Qualcomm의 FlashLinQ 시스템에서는 이러한 링크 스케줄링 과 정을 낮은 복잡도로 쉽게 구현할 수 있도록 단일-톤 (single-tone) 신호 기반의 분산형 링크 스케줄링 기 법을 제안하였다. 모든 단말은 링크간 SIR (Signal-to-Interference Power Ratio) 을 측정하기 위해 단일-톤 OFDM (Orthogonal Frequency Division Multiplexing) 채널을 사용하여 신호를 전 송하며, 측정된 SIR 값과 링크의 우선순위를 함께 고려하여 다른 링크에 통신을 양보 (yielding) 할 것 인지를 결정한다 ${ }^{[3]}$. 이러한 단일-톤 통신 기반 링크 스케줄링 기법에서는 모든 링크가 직교성이 유지되 는 단일-톤 OFDM 채널을 사용하기 때문에, 각 링 크에 해당하는 수신 톤 전력만 측정하여 간단하게 SIR 값을 계산할 수 있다. 하지만 이러한 구조는 다중 경로 채널 환경에서 주파수 선택적 페이딩의 영향으로 전 대역에 대한 실제 채널 전력과 측정된
단일-톤 전력간의 오차가 발생할 수밖에 없으며, 그 로 인한 스케줄링 오류는 네트워크 전체에 대한 전 송률 상의 손실을 가져올 수 있다.

본 논문에서는 이러한 문제를 해결하기 위해 CAZAC (Constant Amplitude Zero Auto-Correlation) 시퀀스 ${ }^{[4]}$ 기반의 새로운 링크 스 케줄링 기법을 제안한다. 제안하는 링크 스케줄링 기법에서는 전체 대역을 다수의 sub-block으로 분할 하고 각 링크의 송신 단말들이 매 sub-block 마다 고유의 순환 오프셋 (cyclic offset) 을 적용한 CAZAC 시퀀스를 전송한다. 수신 단말은 서로 다 른 순환 오프셋이 적용된 CAZAC 시퀀스간에 완벽 한 직교 상관 특성이 보장되는 특성을 이용하여 전 체 대역에 대한 SIR 에 가까운 값을 획득할 수 있 다 ${ }^{[5]}$. 본 논문에서는 컴퓨터 모의 실험 결과를 통해 제안하는 링크 스케줄링 기법을 적용함으로써 기존 FlashLinQ 구조 대비 네트워크 전체 수율 관점에서 우수한 성능을 나타냄을 입증한다.

본 논문의 구성은 다음과 같다. II장에서는 기존 FlashLinQ 시스템의 링크 스케줄링 채널 구조 및 세부 동작 과정에 대하여 서술하고, 단일-톤 기반 링크 스케줄링 구조의 문제점을 분석하여 전체 대 역에 대한 SIR 측정의 필요성을 기술한다. III장에 서는 CAZAC 시퀀스의 상관 특성을 서술하고 이를 활용하기 위한 새로운 링크 스케줄링 채널 구조를 제시한다. 또한, 제안 구조를 적용한 링크 스케줄링 의 세부 동작 과정을 통해 전체 대역에 대한 SIR 측정이 가능함을 증명한다. IV장에서는 컴퓨터 모의 실험 결과 분석을 통해 제안하는 링크 스케줄링 구 조에 대한 성능 평가를 수행한다. 마지막으로 $\mathrm{V}$ 장 에서 결론을 맺는다.

\section{II . FlashLinQ 시스템의 링크 스케줄링}

본 장에서는 FlashLinQ 시스템에서 사용하는 링 크 스케줄링 채널 구조에 대해 설명하고, 전체 링크 스케줄링 동작 과정에 대해 서술한다.

\subsection{FlashLinQ의 링크 스케줄링 채널 구조}

FlashLinQ는 Qualcomm에서 개발한 동기식 OFDM 기반 P2P (Peer-to-Peer) 통신 기술로 약 $1 \mathrm{~km}$ 반경 내 검색된 단말들을 대상으로 분산형 채 널 인식 (channel-aware) 링크 스케줄링이 가능한 시스템이다 ${ }^{[3]}$. FlashLinQ의 링크 스케줄링 과정은 스케줄링 된 모든 링크들이 동시에 일정 수준 이상 


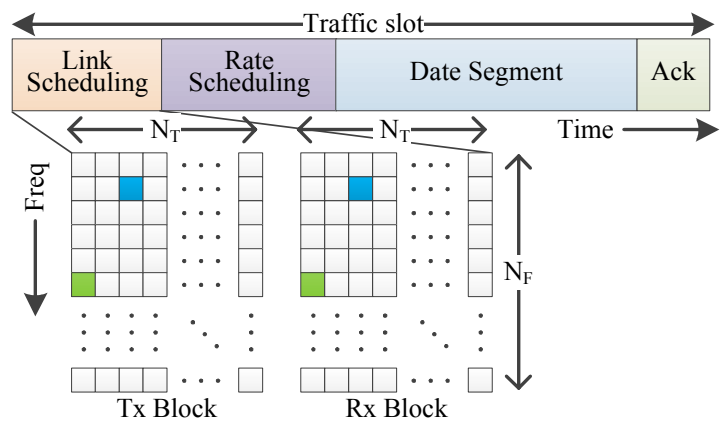

그림 1. FlashLinQ의 링크 스케줄링 채널 구조 ${ }^{[3]}$

Fig. 1. A link scheduling channel structure of FlashLinQ system ${ }^{[3]}$

의 SIR 값을 만족시킬 수 있도록 하기 위해 링크의 우선순위 및 채널 상황을 기반으로 수행되며, 그림 1 과 같은 링크 스케줄링 채널 구조를 가진다. 데이 터 전송은 $2 \mathrm{~ms}$ 의 슬롯 단위로 이루어지며, 각 슬롯 은 link scheduling, rate scheduling, data segment, 그리고 acknowledge 총 4 개의 채널로 구분된다.

Link scheduling 채널은 Tx-block과 Rx-block, 2 개의 블록으로 구성되며 각 블록은 $N_{F}$ 개의 톤들로 이루어진 $N_{T}$ 개의 $\mathrm{OFDM}$ 심벌을 가진다. 모든 링 크는 링크 고유의 CID (Connection ID) 를 가지며, 각각의 $\mathrm{CID}$ 는 사전 결정된 링크의 우선순위에 따라 $N_{T} \times N_{F}$ 크기의 톤-심벌들 중 단일-톤 하나에 대응된 다. 송·수신 단말은 스케줄링을 위해 $\mathrm{Tx} / \mathrm{Rx}$-block 중 각 링크에 할당된 단일-톤을 선택하여 DPS (Direct Power Signal) 및 IPE (Inverse Power Echo) 신호를 전송한다. 이처럼 모든 단말이 링크간 직교성이 보장되는 단일-톤 신호를 사용하기 때문에 실제 데이터를 전송하기 전에 간섭 상황을 대략적 으로 추정할 수 있으며, 수신 단말은 자기 자신의 SIR 뿐만 아니라 다른 수신 단말에서의 SIR을 독 립적으로 추정할 수 있다. 추정된 SIR 값은 각 링 크의 송·수신 단말들이 $\mathrm{Tx}$-yielding 및 $\mathrm{Rx}$-yielding 의 수행 여부를 결정할 때 사용된다. 여기서, Tx-yielding이란 각 링크의 송신 단말이 자신이 전 송하는 신호가 최소 하나 이상의 상위 링크에게 일 정 수준 이상의 간섭을 일으킨다고 판단할 때, 통신 을 상위 링크에 양보하는 것을 의미한다. 반면, Rx-yielding은 각 링크의 수신 단말이 자신의 링크 가 다른 모든 상위 링크들로부터 전송된 간섭 신호 로 인해 일정 수준의 SIR 값을 확보하지 못할 경우 통신을 포기하는 것을 의미한다 ${ }^{[3]}$. Tx/Rx-yielding 수행에 대한 자세한 동작 과정은 본 장의 2절에서 다룬다.

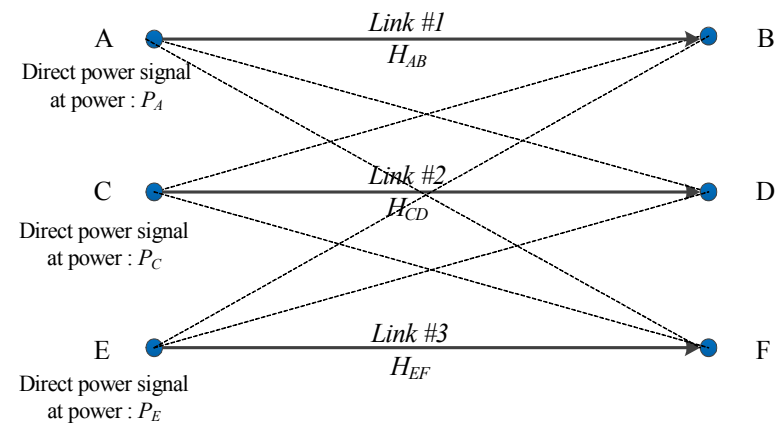

그림 2. 3-링크 스케줄링 예

Fig. 2. Scheduling for 3-link case

Rate scheduling 채널에서는 모든 링크들을 대상 으로 단일-톤 위치에서의 수신 전력만으로 계산하는 link scheduling 채널에서의 SIR 측정과 달리, 스케 줄링 된 링크들만을 대상으로 보다 정교한 $\mathrm{SIR}$ 측 정을 수행한다. 이 과정에서 스케줄링된 링크들은 우선순위와 관계없이 다른 모든 스케줄링된 링크들 을 대상으로 실제 데이터가 전송되는 전체 대역에 대한 SIR을 측정하고, 그에 적합한 변조 방식 및 부호율을 결정한다.

Data segment 채널에서는 스케줄링된 링크의 송 신 단말들이 rate scheduling 채널에서 결정된 변조 방식과 부호율을 적용하여 각자 전체 대역을 사용 하여 데이터를 전송한다. 수신 단말들은 패킷 단위 의 데이터를 성공적으로 수신했는지를 알리기 위해 acknowledgement 신호를 송신 단말로 전송한다.

\section{2. 링크 스케줄링 세부 동작 과정}

FlashLinQ 시스템에서는 그림 1의 링크 스케줄 링 신호 구조 하에서 각 단말들의 통신 수행 여부 를 결정한다. 본 절에서는 FlashLinQ 시스템의 링 크 스케줄링 과정을 설명하기 위해 그림 2의 3-링 크 통신 환경을 고려한다. 그림 2의 통신 환경에서 는 총 6 개의 단말 $\mathrm{A} \sim \mathrm{F}$ 가 3 개의 링크 Link-1 3 을 각각 생성하며, 그로 인해 실선으로 표시된 직 접 링크로 인한 채널 $\left\{H_{A B}, H_{C D}, H_{E F}\right\}$, 그리고 점 선으로 표시된 교차 링크로 인한 채널 $\left\{H_{A D}, H_{A F}\right.$, $\left.H_{B C}, H_{C F}, H_{B E}, H_{D E}\right\}$ 가 형성된다. 각 링크는 고유 의 $\mathrm{CID}$ 를 가지며 각 링크의 송신 단말 $\mathrm{A}, \mathrm{C}, \mathrm{E}$ 는 자신의 우선순위에 해당하는 단일-톤 하나를 선택하 여 DPS 신호를 전송한다. 여기서 Link-1 3은 $1>2>3$ 의 우선순위를 가진다고 가정한다.

먼저, 송신 단말 $\mathrm{A}, \mathrm{C}, \mathrm{E}$ 는 각각 $P_{A}, P_{C}, P_{E}$ 의 전력으로 DPS를 전송한다. 이때, 실제 data 
segment 영역에서의 간섭 상황을 예측하기 위한 것 이 목적이므로 각 링크 별 DPS 신호의 송신 전력 은 data segment 채널에서의 부반송파 별 송신 전 력과 동일한 전력으로 조정된다. Link-1의 수신 단 말 $\mathrm{B}$ 의 경우, 자신의 링크가 최상위 우선순위를 가 지므로 별도의 수신 전력 측정 및 $\mathrm{Rx}$-yielding 수행 에 대한 판단과정 없이 링크를 유지한다. 반면, Link-2 및 Link-3의 수신 단말인 $\mathrm{D}, \mathrm{F}$ 는 각자의 우 선순위 및 SIR 측정 결과를 통해 $\mathrm{Rx}$-yielding 수행 여부를 결정한다. 이때, 실제 data segment 채널에 서 통신을 수행할 링크는 아직 결정되지 않은 상태 이므로, 수신 단말은 단순히 자신보다 높은 우선순 위에 있는 상위 링크들로부터 받는 간섭만을 고려 하여 SIR을 측정한다. 이에 따라, Link-2의 수신 단 말 $\mathrm{D}$ 는 자신보다 우선순위가 높은 링크인 Link-1 및 자신의 링크인 Link-2에 해당하는 톤 위치에서 의 수신 전력인 $P_{A} \times\left|H_{A D}\right|^{2}$ 와 $P_{C} \times\left|H_{C D}\right|^{2}$ 을 기준으로 식 (1)과 같이 $\mathrm{SIR}$ 을 계산할 수 있으며, 측정된 SIR과 사전 설정된 임계치 $\mathrm{XSIR}$ 간의 비교를 통해 식 (2)와 같이 Rx-yielding을 수행 여부를 결정한다 [3]

$$
\begin{aligned}
S I R_{D}= & \frac{P_{C} \times\left|H_{C D}\right|^{2}}{P_{A} \times\left|H_{A D}\right|^{2}} \\
& \text { if }\left\{\begin{array}{l}
S I R_{D}<\gamma_{S I R}, \text { Rx-yielding } \\
S I R_{D} \geq \gamma_{S I R}, \text { no Rx-yielding }
\end{array}\right.
\end{aligned}
$$

이와 유사하게, Link-3의 수신 단말 $\mathrm{F}$ 는 자신보 다 우선순위가 높은 Link-1과 Link-2를 모두 간섭 원으로 간주하여 식 (3)과 같은 SIR 추정을 수행하 고, 식 (4)와 같이 Rx-yielding 수행 여부를 결정한 다.

$$
\begin{gathered}
S I R_{F}=\frac{P_{E} \times\left|H_{E F}\right|^{2}}{P_{A} \times\left|H_{A F}\right|^{2}+P_{C} \times\left|H_{C F}\right|^{2}} \\
\text { if }\left\{\begin{array}{l}
S I R_{F}<\gamma_{S I R}, R x-\text { yielding } \\
S_{F} \geq \gamma_{S I R}, \text { no } R x-\text { yielding }
\end{array}\right.
\end{gathered}
$$

Rx-yielding 과정이 끝나면, 수신 단말 $\mathrm{B}, \mathrm{D}, \mathrm{F}$ 중 Rx-yielding을 수행하지 않은 단말은 Rx-block 내 자신에게 할당된 단일-톤을 사용하여 IPE 신호 를 전송한다. 여기서 IPE 신호는 각 링크의 수신 단말이 각 링크의 DPS 수신 전력을 타 링크의 송 신 단말들에게 알리기 위한 목적으로 전송하며, IPE 의 송신 전력은 수신된 DPS 신호 중 자신의 링크 에 할당된 톤 위치에서 측정된 수신 전력의 역으로
설정된다. 수신 단말 B의 경우, Link-1보다 높은 우 선순위를 가지는 링크가 존재하지 않으므로 Rx-yielding을 수행하지 않고 Link-1에 해당하는 수 신 톤 전력의 역수인 $K /\left(P_{A} \times\left|H_{A B}\right|^{2}\right)$ 의 전력으로 IPE 신호를 전송한다. 여기서 $K$ 는 시스템 환경에 적합 하게 설계된 상수 값이다. 마찬가지로, 수신 단말 D 와 $\mathrm{F}$ 역시 Rx-yielding을 수행하지 않았다면 각각 $K /\left(P_{C} \times\left|H_{C D}\right|^{2}\right), K /\left(P_{E} \times\left|H_{E F}\right|^{2}\right)$ 의 전력으로 IPE 신호 를 전송하며, Rx-yielding을 수행했다면 어떠한 응 답 신호도 보내지 않는다.

각 링크의 송신 단말인 $\mathrm{A}, \mathrm{C}, \mathrm{E}$ 는 수신 단말 $\mathrm{B}$, $\mathrm{D}, \mathrm{F}$ 로부터 전송된 IPE 신호를 통해 자신의 링크가 간섭으로 작용하는 상위 링크의 수신 단말에서의 $\mathrm{SIR}$ 값을 간접적으로 측정한다. 단말 $\mathrm{A}$ 의 경우 최 상위 링크에 속하므로 어떠한 측정과정 없이 링크 를 유지한다. 단말 $\mathrm{C}$ 의 경우, Link-1에 해당하는 톤 위치에서 단말 $\mathrm{B}$ 가 전송한 IPE 신호의 수신 전력 $R_{C \leftrightarrow B}=\left(K\left|H_{B C}\right|^{2}\right) /\left(P_{A} \times\left|H_{A B}\right|^{2}\right)$ 을 측정할 수 있으며, 단 말 $\mathrm{C}$ 는 $R_{C \leftarrow B}$ 를 통해 식 (5)와 같이 자신이 전송할 신호로 인한 단말 $\mathrm{B}$ 에서의 $\mathrm{SIR}$ 을 간접적으로 측정 할 수 있다.

$$
S I R_{B \leftarrow C}=\frac{P_{A} \times\left|H_{A B}\right|^{2}}{P_{C} \times\left|H_{B C}\right|^{2}}=\frac{K}{R_{C \leftarrow B} \times P_{C}}
$$

여기서 $S I R_{B \leftarrow C}$ 는 단말 C로부터의 간섭 신호로 인한 단말 $\mathrm{B}$ 에서의 $\mathrm{SIR}$ 을 의미한다. 단말 $\mathrm{C}$ 는 식 (6)과 같이, 측정된 SIR이 사전에 설정된 임계치보 다 작을 경우, Tx-yielding 을 수행하여 통신을 Link-1에게 양보한다.

$$
\text { if }\left\{\begin{array}{l}
S I R_{B \leftarrow C}<\gamma_{S I R}, T x-\text { yielding } \\
S I R_{B \leftarrow C} \geq \gamma_{S I R}, \text { no Tx-yielding }
\end{array}\right.
$$

단말 $\mathrm{E}$ 역시 위와 유사한 과정을 통해 Tx-yielding 수행 여부를 결정한다. 단, 단말 $\mathrm{E}$ 의 경우 Link-1, 2 모두 자신이 속한 Link-3보다 높은 우선순위를 가지므로, 두 링크 모두에 대해 SIR을 따로 계산할 필요가 있다. 식 (5)와 유사하게 단말 $\mathrm{E}$ 로부터의 간섭 신호로 인한 수신 단말 $\mathrm{B}, \mathrm{D}$ 에 서의 $S_{1 R_{B} \leftarrow E}, S I R_{D \leftarrow E}$ 은 각각 $K /\left(R_{E \leftarrow B} \times P_{E}\right), K /\left(R_{E}\right.$ $\left.{ }_{D} \times P_{E}\right)$ 으로 구할 수 있으며, 식 (7)과 같이 두 개의 상위 링크에서의 SIR 중, 단 하나라도 임계값을 넘 지 못한다면 Tx-yielding을 수행하여 통신을 양보한 다. 


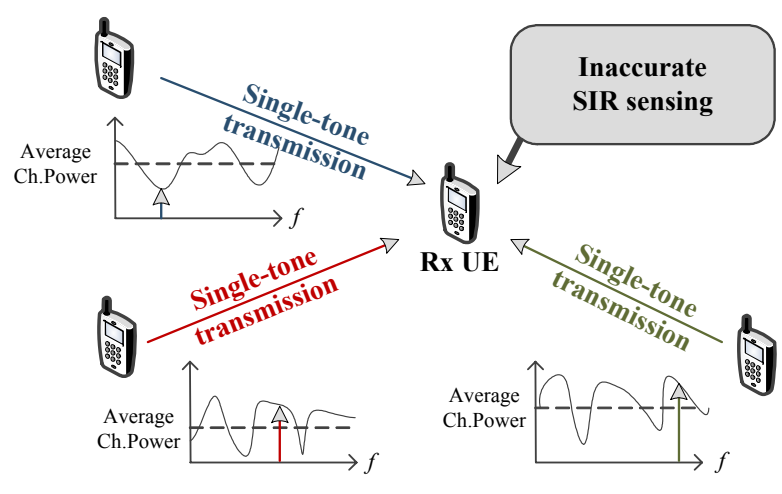

그림 3. 단일-톤 통신 기반 링크 스케줄링의 문제점

Fig. 3. A problem in single-tone based link scheduling

$$
\text { if }\left\{\begin{array}{l}
S I R_{B \leftarrow-E}<\gamma_{S I R} \text { or } S I R_{D \leftarrow E}<\gamma_{S I R} \text { Tx-yielding } \\
S I R_{B \leftarrow-E} \geq \gamma_{S I R} \text { and } S I R_{D \leftarrow E} \geq \gamma_{S I R} \text { no Tx-yielding }
\end{array}\right.
$$

이와 같이 FlashLinQ 시스템에서의 링크 스케줄 링은 각 링크의 우선순위와 상위 링크에 대한 SIR 모두를 고려하여 수행되며, 각 링크의 우선순위는 링크간 공평성 (fairness)을 보장하기 위해 매 트래 픽 슬롯마다 임의로 설정된다 ${ }^{[3]}$.

\section{3. 단일-톤 통신 기반 링크 스케줄링의 문제점}

FlashLinQ 시스템의 link scheduling 채널에서는 단일-톤 위치에서의 수신 전력만을 고려하는 반면, 실제 데이터 전송이 이루어지는 data segment 채널 에서는 OFDM 채널의 전체 대역을 사용하여 데이 터를 전송한다. 따라서, 링크 스케줄링을 위한 DPS 및 IPE 신호를 전체 대역이 아닌 단일 톤-심볼을 통해 전송하는 경우, 실제 데이터 전송이 이루어지 는 전체 대역에 대한 정확한 SIR 정보 획득이 불가 능하다. 특히, 그림 3 과 같이 다중 경로 채널 환경 에서의 주파수 선택적 페이딩에 의한 영향으로, 단 일-톤 위치에서의 수신 전력과 전체 대역에 대한 수 신 전력 간에 큰 차이가 발생할 수 있다. 수신 전 력 측정에서의 오차는 SIR 측정 시에도 반영되며, 전체 대역에 대한 SIR 고려 시 통신이 가능함에도 통신을 포기하거나, 간섭이 많아 통신이 어려움에도 통신을 시도하는 스케줄링 과정상의 오류를 일으킨 다. 이러한 스케줄링 오류는 공평성 측면에서 문제 가 될 뿐만 아니라 셀 전체에 대한 전송률 상의 손 실을 발생시킬 수 있다. 이러한 문제점을 개선하기 위해서는 링크 스케줄링 과정에서 전체 대역에 대 한 SIR 정보를 획득할 수 있는 신호 구조에 대한 설계가 요구된다.

\section{III. 제안하는 링크 스케줄링 기법}

본 장에서는 단일-톤 기반 링크 스케줄링 구조의 문제점을 개선 가능한 구조로서, CAZAC 시퀀스 기반의 새로운 링크 스케줄링 채널 구조 및 세부 동작 과정을 제시한다. CAZAC 시퀀스의 순환 자 기 상관 연산 (cyclic auto-correlation) 특성을 링크 스케줄링 구조에 활용하는 방안을 설명하고, 이러한 특성을 효과적으로 사용할 수 있는 새로운 링크 스 케줄링 채널 구조를 제시한다. 또한, 제안하는 구조 로 전송된 신호로부터 전체 대역에 대한 평균 수신 전력을 획득하는 방법 및 $\mathrm{SIR}$ 측정 과정을 제시한 다.

3.1. $\mathrm{CAZAC}$ 시퀀스 기반 링크 스케줄링 채널 구조

본 절에서는 $\mathrm{D} 2 \mathrm{D}$ 통신을 위한 분산형 링크 스 케줄링에서도 전체 대역에 대한 SIR 측정이 가능한 새로운 링크 스케줄링 채널 구조를 제안한다. II.3절 에서 언급한 바와 같이, FlashLinQ 시스템의 스케 줄링 오류 문제를 해결하기 위해서는 전체 대역에 대한 SIR 측정이 필요하다. 하지만, 이를 위해 모든 단말이 OFDM 채널의 전 대역에 걸쳐 신호를 전송 한다면 각 링크로부터 전송된 신호간 직교성은 더 이상 보장되지 않는다. 따라서 제안하는 링크 스케 줄링 기법에서는 모든 단말이 전체 대역을 사용하 면서도 상호간 직교성을 유지하도록 하기 위해 $\mathrm{CAZAC}$ 시퀀스의 상관 연산 특성을 이용한다 ${ }^{[4]}$.

본 논문에서는 다양한 CAZAC 시퀀스들 중 식 (8)에 나타난 ZC (Zadoff-Chu) 시퀀스를 고려한다 [5]

$$
\not(k)=\exp \left[-\frac{j 2 \pi r}{N}\left(\frac{k^{2}}{2}\right)\right], k=0,1, \cdots, N-1
$$

식 (8)에서 $N$ 은 짝수인 정수, 그리고 $r$ 은 $N$ 과 서로소 관계인 root index를 나타낸다. $\mathrm{ZC}$ 시퀀 스는 식 (8)에서 확인할 수 있듯이 인덱스 $k$ 에 따 라 위상은 변하지만 모두 동일한 진폭을 가진다. 또 한, $\mathrm{ZC}$ 시퀀스의 자기 상관 함수 $R(j)$ 는 식 (9)과 같이, 무선 채널의 시간주파수 선택적 특성이 제한 된 환경 하에서 서로 다른 순환 오프셋이 적용된 시퀀스 간에 완벽한 직교 상관 특성이 보장되는 특 성을 가진다 ${ }^{[4]}$.

$$
\begin{array}{r}
R(j)=\sum_{k=0}^{N-1} Z(k) Z^{*}(k \ominus j)=\left\{\begin{array}{l}
0, j \neq 0 \\
N, j=0
\end{array}\right. \\
(\ominus: \text { Cyclic offset operator })
\end{array}
$$




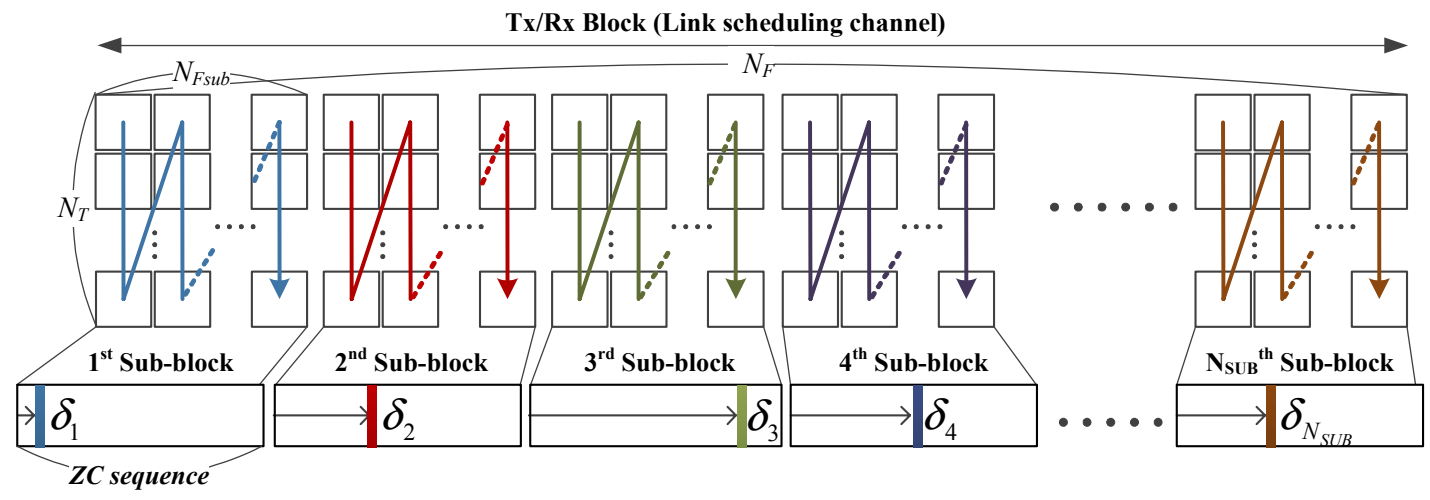

그림 4. CAZAC 시퀀스 기반 링크 스케줄링 채널 구조

Fig. 4. CAZAC sequence based link scheduling channel structure

여기서, $j$ 는 $0 \sim N-1$ 의 값을 가진다.

본 논문에서는 식 (9)와 같은 CAZAC 시퀀스의 이상적인 상관 특성을 링크 스케줄링 시 동시 전송 된 각 링크 별 신호의 구분을 위해 활용한다. 그림 4는 본 논문에서 제안하는 link scheduling 채널 구 조를 나타낸다. 제안하는 구조에서는 $N_{T} \times N_{F}$ 크기에 해당하는 Tx/Rx block 이 $N_{T} \times N_{F s u b}$ 의 크기를 갖는

$N_{s u b}$ 개의 sub-block으로 분할되어 있으며, 각각의 sub-block 내에서는 채널 시간주파수 축 상에서의 변화량이 크지 않은 평탄 페이딩 조건이 만족된다 고 가정한다. 이러한 구조 하에서 각 링크의 송.수 신 단말은 DPS 및 IPE 신호 전송 시 우선순위에 따라 사전 결정된 순환 오프셋 $\left\{\delta_{1}, \delta_{2}, \cdots, \delta_{\text {Nubb }}\right\}$ 을 적용한 $N_{s u b}$ 개의 $\mathrm{ZC}$ 시퀀스를 생성하여 각각의 sub-block을 통해 전송한다. 이 경우, 모든 링크의 전송 신호가 전체 대역에서 중첩되지만, sub-block 단위로 고유의 순환 오프셋이 적용됨에 따라 발생 하는 직교 상관 특성을 활용하여 수신 측에서 각 링크의 sub-block 별 수신 전력을 검출할 수 있다.

\section{2. 링크 스케줄링 세부 동작 과정}

II.2절에서 고려한 그림 2의 3-링크 통신 환경을 재차 고려하여 제안 기법의 세부 동작 과정을 설명 한다. 제안 기법 적용 시 Link-1의 송신 단말 $\mathrm{A}$ 는 DPS 로서 $N_{\text {sub }}$ 개의 sub-block마다 $N_{T} \times N_{F s u b}$ 길이의 $\mathrm{ZC}$ 시퀀스를 $P_{A}$ 의 송신 전력으로 각각 전송한다. 각 sub-block으로 전송되는 $\mathrm{ZC}$ 시퀀스에는 우선순 위에 따라 사전 결정된 순환 오프셋 $\left\{\delta_{1,1}, \delta_{1,2}, \cdots\right.$, $\left.\delta_{l, \text { Nsub }}\right\}$ 이 적용된다. 여기서 $\delta_{l, i}$ 는 Link-1의 $i$ 번 째 sub-block에 적용되는 순환 오프셋 값을 의미한 다. 마찬가지로 Link-2, 3의 송신 단말인 $\mathrm{C}$ 와 $\mathrm{E}$ 는 각각 $P_{C}, P_{E}$ 의 전력으로 순환 오프셋 $\left\{\delta_{2,1}, \delta_{2,2}\right.$, $\left.\cdots, \delta_{2, N \text { sub }}\right\}, \quad\left\{\delta_{3,1}, \delta_{3,2}, \cdots, \delta_{3, N \text { sub }}\right\}$ 이 적용된 $\mathrm{ZC}$ 시퀀스들을 전송한다. 따라서, 송신 단말 $\mathrm{A}, \mathrm{C}, \mathrm{E}$ 가 $i$ 번째 sub-block을 통해 전송한 신호, $S_{A, i}, S_{C, i}, S_{E, i}$ 는 식 (10)과 같이 표현할 수 있다.

$$
\begin{aligned}
& S_{A, i}(k)=\sqrt{P_{A}} \times \not\left(k \ominus \delta_{1, i}\right) \\
& S_{C, i}(k)=\sqrt{P_{C}} \times Z\left(k \ominus \delta_{2, i}\right) \\
& S_{E, i}(k)=\sqrt{P_{E}} \times Z\left(k \ominus \delta_{3, i}\right)
\end{aligned}
$$

여기서 $i$ 는 $1 \sim N_{\text {sub }}$ 의 값을, $k$ 는 $0 \sim$ $N_{T} \times N_{F s u b}-1$ 의 값을 가진다.

수신 단말 $\mathrm{B}, \mathrm{D}, \mathrm{F}$ 는 직접 링크 및 교차 링크 들을 통해 식 (10)의 신호들이 중첩된 신호를 수신 한다. Link-2의 수신 단말 $\mathrm{D}$ 의 경우 수신한 $i$ 번 째 sub-block 에서의 신호 $Y_{D, i}$ 는 식 (11)과 같다.

$$
Y_{D, i}(k)=H_{C D, i} S_{C, i}(k)+H_{A D, i} S_{A, i}(k)+H_{D E, i} S_{E, i}(k)
$$

단말 $\mathrm{D}$ 는 $i$ 번째 sub-block에서 상위 링크인 Link-1에 의한 간섭 신호 및 Link-2의 평균 수신 신호 전력을 측정하기 위해 식 (12)와 같이 $Y_{D, i}$ 와 참조 신호 $Z_{i}(k)$ 간의 순환 상호 상관 연산을 수행 한다.

$$
R_{i}(j)=\frac{1}{N_{T} \times N_{F_{\text {SlB }}}} \sum_{k=0}^{N_{T} \times N_{F}-1} Y_{D, i}(k) Z^{*}(k \ominus j)
$$

여기서, 식 (10)과 (11)을 식 (12)에 대입하면, 식 (13)의 결과를 얻을 수 있다.

$$
\begin{array}{r}
R_{i}(j)=\frac{\sqrt{P_{C}} H_{C D, i}}{N_{T} \times N_{F_{S B B}}} \sum_{k=0}^{N_{T} \times N_{F}-1} Z\left(k+\delta_{2, i}\right) Z^{*}(k \ominus j) \\
+\frac{\sqrt{P_{C}} H_{C D, i}}{N_{T} \times N_{F_{S B B}} \times N_{F}-1} \sum_{k=0}^{N_{S=0}} Z\left(k+\delta_{2, i}\right) Z^{*}(k \ominus j) \\
+\frac{\sqrt{P_{C}} H_{C D, i}}{N_{T} \times N_{F_{S I B}}} \sum_{k=0}^{N_{T} \times N_{F}-1} Z\left(k+\delta_{2, i}\right) Z^{*}(k \ominus j)
\end{array}
$$


식 (13)의 연산 결과는 $\mathrm{ZC}$ 시퀀스의 순환 자기 상관 특성에 의해 식 (14)와 같이 4 개의 다른 값 을 가진다.

$$
R_{i}(j)=\left\{\begin{array}{cc}
H_{A D, i} \sqrt{P_{A}}, & j=\delta_{1, i} \\
H_{C D, i} \sqrt{P_{C}}, & j=\delta_{2, i} \\
H_{D E, i} \sqrt{P_{E}}, & j=\delta_{3, i} \\
0, & \text { otherwise }
\end{array}\right.
$$

각 링크가 적용한 sub-block 별 순환 오프셋 값 들은 우선순위에 따라 사전 결정되어 있어 모든 단 말들이 공유하고 있다고 가정할 수 있다. 따라서, 단말 $\mathrm{D}$ 는 식 (12)의 상호 상관 연산 결과에서 Link-1과 Link-2에 해당하는 오프셋인 $j=\delta_{I, i}$ 와 $j=\delta_{2, i}$ 에 대응되는 상관 연산 값만 획득함으로써, 단말 $\mathrm{A}$, $\mathrm{C}$ 로부터 전송된 신호의 $i$ 번째 sub-block 에서의 평균 수신 전력을 측정할 수 있다. 이상의 전력 검 출 과정을 모든 sub-block에 대해 동일하게 적용함 으로써, 식 (15)와 같이 단말 $\mathrm{A}$ 와 $\mathrm{C}$ 로부터 전송된 신호의 전체 대역에 대한 평균 수신 전력을 측정할 수 있다.

$$
\begin{aligned}
& E\left(P_{A}\left|H_{A D}\right|^{2}\right)=\frac{1}{N_{S U B}} \sum_{i=1}^{N_{S B B}}\left|R_{i}\left(\delta_{1, i}\right)\right|^{2} \\
& E\left(P_{C}\left|H_{C D}\right|^{2}\right)=\frac{1}{N_{S U B}} \sum_{i=1}^{N_{S I B}}\left|R_{i}\left(\delta_{2, i}\right)\right|^{2}
\end{aligned}
$$

전력 검출 이후 수행되는 SIR 기반의 Rx-yielding 절차는 II.2절의 기존 기법과 동일한 방 법으로 진행되며, 단말 $\mathrm{E}$ 에서의 Rx-yielding 절차 또한 앞서 설명한 바와 같은 상호 상관 기반의 전 력 검출을 통해 수행될 수 있다. 한편, 제안 기법의 Rx-block에서 전송되는 IPE 신호의 구성 또한 앞서 설명한 Tx-block에서의 DPS 신호 전송 방법과 동 일하게 sub-block 단위로 $\mathrm{ZC}$ 시퀀스를 전송하되, 각 부반송파 별 송신 전력은 측정된 평균 수신 전 력의 역수로 구성함으로써 Tx-yielding 시 각 링크 의 송신 단말이 수신 측의 SIR 정보를 획득할 수 있도록 한다. 결과적으로, 제안 구조는 SIR 정보와 우선순위에 따른 yielding 절차는 기존 II.2 절의 기 존 기법과 동일하되, 다중 경로 채널 환경에서 전체 대역에 대한 SIR 정보를 상대적으로 정확히 측정할 수 있는 방식이다.

한편, 제안 구조 적용 시 모든 링크가 각 sub-block에서 각기 다른 순환 오프셋 값을 적용해 시퀀스 전송을 수행하기 위해서는 링크의 수가 $N_{T} \times N_{S U B}$ 로 제한되어야 하며, 그 이상의 링크가 존 재하는 경우 특정 sub-block 내에서 링크 간 순환
오프셋 적용치의 중첩이 불가피하게 발생한다. 이는 하나의 sub-block 내에서 적용 가능한 순환 오프셋 값의 범위가 한정적임으로 인해 발생하는 문제이다. 하나의 sub-block 내에서 동일한 순환 오프셋 값을 적용한 링크의 신호 간에는 상관 연산의 직교성이 더 이상 보장되지 않으므로, 중첩된 링크들은 해당 sub-block 내에서 정확한 수신 전력 측정이 어려우 며, 만약 링크간 순환 오프셋 중첩이 모든 sub-block 에서 발생하면 해당 링크의 전체 평균 수 신 전력 측정이 불가능하게 된다. 이러한 특정 링크 의 수신 전력 측정 불가 문제를 방지하기 위해, 사 전 순환 오프셋 적용 패턴 생성 시, 링크마다 적어 도 하나 이상의 sub-block에서는 타 링크와 순환 오 프셋 적용 값이 중첩되지 않도록 하는 패턴을 설계 할 필요가 있다. 이러한 패턴 사전 설계가 수행되는 경우, 모든 $\mathrm{D} 2 \mathrm{D}$ 단말이 해당 패턴 정보를 통해 각 sub-block에 대한 링크간 순환 오프셋 중첩 발생 여 부를 사전에 알 수 있으므로, 평균 수신 전력 계산 시 중첩이 발생하지 않은 sub-block 만을 선택적으 로 사용하여 전체 대역에 대한 평균 수신 전력 측 정을 수행한다. 이에 따라 식 (15)의 평균 전력 측 정 과정은 다음의 식 (16)과 같이 변형된다.

$$
\begin{aligned}
& E\left(P_{A}\left|H_{A D}\right|^{2}\right)=\frac{1}{N_{u_{1}}} \sum_{u_{1}}\left|R_{u_{1}}\left(\delta_{1, u_{1}}\right)\right|^{2} \\
& E\left(P_{C}\left|H_{C D}\right|^{2}\right)=\frac{1}{N_{u_{2}}} \sum_{u_{2}}\left|R_{u_{2}}\left(\delta_{2, u_{2}}\right)\right|^{2}
\end{aligned}
$$

여기서, 인덱스 $u_{1}, u_{2}$ 는 각각 Link-1, 2에 적용 된 순환 오프셋 패턴에서 중첩이 발생하지 않은 sub-block의 인덱스를 의미하며, $N_{u 1}$ 과 $N_{u 2}$ 는 각 링크에 중첩이 발생하지 않은 sub-block의 개수를 의미한다.

이러한 링크 별 순환 오프셋의 중첩 빈도는 링크 스케줄링에 참여하는 링크의 수에 비례하므로, 링크 의 수가 많을수록 평균 수신 전력 측정을 위해 활용 할 수 있는 sub-block 의 수가 감소해 측정치의 오 차가 증가한다. 그러나 최소 하나 이상의 sub-block 에서 수신 전력 측정이 가능하도록 사전 패턴이 설 계됨을 고려하면, 최악의 경우에도 기존의 단일-톤 구조와 유사한 정확도로 SIR 측정이 가능하며 통신 을 시도하는 링크의 수가 적은 환경에서는 매우 높 은 정확도로 SIR 측정이 가능하다. 


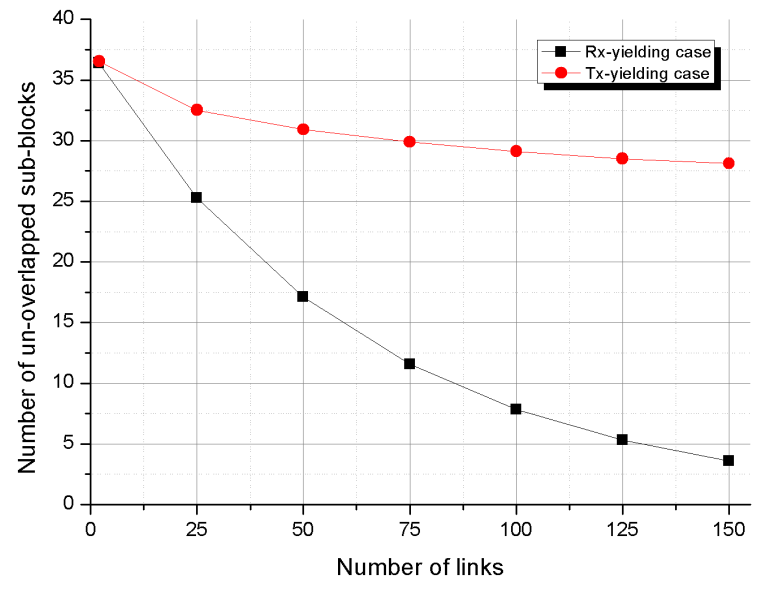

그림 5. Tx/Rx-block 내 중첩이 되지 않은 sub-block 수 $\left(N_{S U B}=40, N_{T} \times N_{F}=4 \times 15\right)$

Fig. 5. The number of un-overlapped sub-blocks in Tx/Rx-block $\left(N_{S U B}=40, N_{T} \times N_{F}=4 \times 15\right)$

뿐만 아니라, 제안 구조는 Rx-block에서 더욱 높 은 SIR 추정 정확도를 보장할 수 있다. 이는 Tx-block이 전송된 이후 각 링크의 수신 단말들이 Rx-yielding을 수행함에 따라 상당수의 링크가 자신 의 간섭 상황을 인지하여 통신을 포기하게 되므로, Rx-block에서의 IPE 전송을 시도하는 링크는 Tx-block에서 DPS를 전송한 링크의 수와 비교해 크게 줄어들기 때문이다. 즉, 비록 Tx-block에서의 DPS 전송 시에는 다수의 링크가 동시 전송을 수행 함으로 인해 sub-block 단위의 순환 오프셋 값의 중 첩이 다수 발생하더라도, 그 이후 수행되는 Rx-block에서의 IPE 전송 시에는 상대적으로 소수 의 생존 링크들만이 전송을 시도하는 특성상 순환 오프셋의 중첩 빈도가 크게 낮아져 정확한 SIR 검 출이 가능하다. 그림 5 는 이러한 중첩 빈도의 비대 칭성을 입증하는 실험 결과로서, 전체 링크 수에 따 른 중첩이 발생하지 않은 sub-block의 평균 개수 측 면에서 Tx-block과 Rx-block 간에 큰 차이가 있음 을 확인할 수 있다.

제안 기법의 경우, FlashLinQ의 단일-톤 기반 구 조 대비 링크 스케줄링 수행 시 더 많은 양의 무선 자원이 필요하다. 하지만 각 링크들의 SIR 계산 시, 우선순위가 높은 링크들의 수신 전력이 더 많이 참 조된다는 것을 고려하면, 상위 링크의 수신 전력 측 정의 정확도가 링크 스케줄링 정확도에도 큰 영향 을 끼치는 것을 알 수 있다. 따라서 실제 시스템에 적용 시에는 우선순위가 높은 일부 링크에만 한정 적으로 제안 기법을 적용하고 우선순위가 낮은 링 크들에는 단일 톤 구조를 적용함으로써, 기존 기법
대비 더 정확한 스케줄링을 수행함과 동시에 무선 자원의 증가량을 적정 수준으로 제한할 수 있다.

따라서, 제안 구조에서는 통신 환경과 무관하게 항상 하나의 부반송파로부터 수신 전력을 측정하는 기존 FlashLinQ 구조와 달리 최소 하나 이상의 sub-block에서의 전력 검출을 보장하면서 전송을 시 도하는 링크의 수 및 링크 스케줄링 과정에서 Tx/Rx-yielding이 이루어짐에 따라 생존 링크에게 더욱 높은 SIR 추정 정확도를 제공할 수 있다.

\section{3. 연산 복잡도 비교}

본 절에서는 기존 구조 및 제안 구조 간의 연산 복잡도 비교를 수행한다. 연산 복잡도는 최대 복잡 도를 기준으로 비교하기 위해 상대적으로 더 많은 링크들을 대상으로 하는 Rx-yielding 수행 절차를 고려하며, 수신 단말 측에서 수행되는 전력 검출 연 산 및 상호 상관 연산 과정에 따른 복소 곱셈 연산 의 수로 비교한다.

하나의 특정 링크보다 더 높은 우선순위를 갖는 링크의 수를 $N_{h i g h-p r}$ 라 할 때, 기존 FlashLinQ의 수신 단말은 SIR 계산 시 단지 $N_{h i g h-p r}$ 개 링크만큼 의 전력 검출과정만 필요하므로, 전체 복소 곱셈 연 산 수는 $N_{h i g h-p r}$ 와 같다. 반면, 제안 기법의 경우 하나의 sub-block에서의 평균 수신 전력을 계산하기 위해, 상관 연산을 위한 $N_{s u b}$ 번의 복소 곱셈 연산 과 한번의 전력 검출 연산이 필요하다. 이 과정을 링크간 순환 오프셋이 중첩되지 않은 sub-block 수 인 $N_{u}$ 만큼 반복 수행해야 하며, 이를 모든 상위 링크에 대해 수행해야 하므로 전체 복소 곱셈 연산 수는 식 (17)과 같다.

$$
\left(N_{S U B}+1\right) \times N_{u} \times N_{\text {high }-p r}
$$

셀 내에 150 개의 $\mathrm{D} 2 \mathrm{D}$ 링크가 존재하는 환경을 고려하면 그림 5 의 결과로부터 $N_{u}$ 는 약 3 의 값을 가지며, 이 경우 제안 기법은 기존 기법 대비 약 $3\left(N_{s u b}+1\right)$ 배의 복잡도가 요구됨을 알 수 있다. 더 욱이 제안 기법의 연산 복잡도는 $N_{h i g h-p r}$ 에 비례하 므로 우선순위가 낮은 링크의 경우 기존 기법 대비 매우 높은 연산 복잡도를 갖게 되어 구현상의 문제 가 발생할 수 있다. 


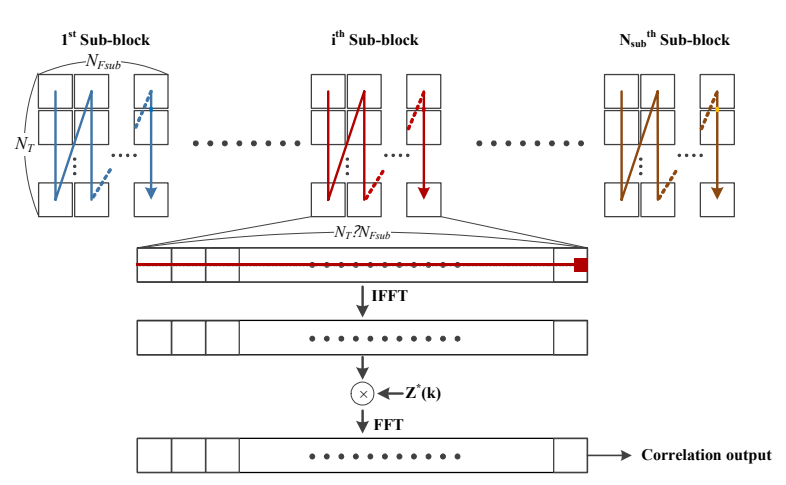

그림 6. IFFT/FFT 변환을 이용하는 상관 연산 과정

Fig. 6. A correlation procedure using IFFT/FFT

이를 해결하기 위한 방법으로, 우선순위가 낮은 링크에 한해서 고속 푸리에 변환 (FFT: Fast Fourier Transform) 을 이용하는 상관 연산 방법을 적용할 수 있다. 그림 6과 같이 하나의 sub-block 내 수신 신호에 역 고속 푸리에 변환 (IFFT: Inverse Fast Fourier Transform) 수행 후 참조 신 호와의 상관 연산을 수행하고, 그 결과를 다시 FFT 하게 되면 상기 상호 상관 연산을 모든 링크에 대 해 수행한 것과 동일한 결과를 얻을 수 있다. 각각 한 번의 IFFT, FFT 연산, 그리고 한 번의 참조 신 호와의 상관 연산 및 전력 검출 과정이 필요하므로 sub-block 하나에 대해 전체 링크의 평균 수신 전력 을 얻는데 필요한 복소 곱셈의 수는 식 (18)과 같이 나타낼 수 있다.

$$
\begin{aligned}
& \underbrace{N_{S U B} \log \left(N_{S U B}\right)}_{I F F T}+\underbrace{N_{S U B} \log \left(N_{S U B}\right)}_{F F T} \\
& +\underbrace{N_{S U B}}_{\text {power detection }}+\underbrace{N_{S U B}}_{\text {reference }}=2 N_{S U B} \log \left(N_{S U B}\right)+2 N_{S U B}
\end{aligned}
$$

식 (18)의 연산 과정은 기존 상호 상관 연산 수 행 과정인 식 (17)과는 달리 $N_{h i g h-p r}$ 에 무관한 복잡 도를 가지며, $N_{h i g h-p r}$ 가 큰 값을 가지는 경우 식 (17) 보다 낮은 복잡도를 보인다. 따라서, 각 단말 은 자신의 우선순위 및 자신 보다 높은 우선순위를 가지는 링크의 수를 고려하여 식 (17)의 주파수 영 역 상호 상관 연산 또는 식 (18)의 푸리에 변환을 이용한 상관 연산 가운데 복잡도가 낮은 한 가지 방식을 선택하여 적용함으로써 각 링크의 수신 전 력을 검출할 수 있다. 이 경우, 비록 기존의 단일톤 기법 대비 큰 복잡도를 가지지만 구현 가능한 수준의 복잡도 이내에서 제안 기법의 구현이 가능 하다.

\section{IV. 컴퓨터 모의 실험}

본 장에서는 컴퓨터 모의 실험을 통해 본 논문에 서 제안한 링크 스케줄링 기법과 기존 FlashLinQ 시스템의 링크 스케줄링 기법간의 비교를 위해 다 양한 관점에서의 평가를 수행한다. 두 기법간의 비 교는 스케줄링 오류율, 스케줄링 된 링크들에 대한 SINR CCDF (Complementary Cumulative Distribution Function) 및 전체 전송률 관점에서 수 행된다. 각 모의 실험은 $1 \mathrm{~km}^{2}$ 의 정사각형 셀, 대역 폭 $5 \mathrm{MHz}$ 를 고려하여 진행되었다. 표 1 은 모의 실 험에 적용된 주요 파라미터들을 정리한 것이다. 본 논문의 제안 구조 적용 시 고려되는 sub-block의 시 간 영역 크기는 기존 구조와 동일하게 4 개의 OFDM 심벌을 고려하였으며, 주파수 영역 크기는 다중 경로 채널 모델인 $802.11 \mathrm{TGn}$ model $\mathrm{B}^{[6]}$ 채 널 모델의 주파수 선택적 특성을 고려한 사전 모의 실험을 통해 6 개의 부반송파로 설정하였다. 또한, 수용 가능한 링크 수 증가를 위해 전체 sub-block을 짝수, 홀수의 두 그룹으로 나누어 단말에 따라 하나 의 그룹을 선택적으로 사용하는 구조를 적용하였다.

표 1. 주요 시스템 파라미터

Table 1. System parameters

\begin{tabular}{|l|l|}
\hline Parameter & Value \\
\hline \hline Carrier frequency & $2.4 \mathrm{GHz}$ \\
\hline Bandwidth & $5 \mathrm{GHz}$ \\
\hline FFT size $\left(N_{\text {FFT }}\right)$ & 512 \\
\hline The number of used subcarriers & 300 subcarriers \\
\hline The number of sub-blocks & 50 \\
\hline Sub-block size & $4 \times 6$ \\
\hline Maximum link length & $100 / 200 / 500 \mathrm{~m}$ \\
\hline SIR threshold for yielding & $9 \mathrm{~dB}, 18 \mathrm{~dB}$ \\
\hline Multi-path channel model & 802.11 TGn model B \\
\hline The number of links & $2 \sim 105$ \\
\hline Geographical shape & $1 \mathrm{~km}{ }^{2}$ square, uniform \\
\hline Pathloss model & $\begin{array}{l}\text { ITU-R UMi pathloss } \\
\text { model }\end{array}$ \\
\hline Transmit power & $20 \mathrm{dBm}$ \\
\hline Noise power/Noise figure & $-174 \mathrm{dBm} / 7 \mathrm{~dB}$ \\
\hline Antenna loss & $-2.5 \mathrm{~dB}$ \\
\hline Log-normal shadowing & $\begin{array}{l}0 \text { mean, Stdev. 10 dB, } \\
\text { Gaussian random }\end{array}$ \\
\hline & $\begin{array}{l}\text { Look-Up-Table of DL } \\
\text { Throughput vs. SINR } \\
\text { for Baselink E-UTRA } \\
\text { Coexistence Studies }\end{array}$ \\
\hline MCS table & \\
\hline
\end{tabular}




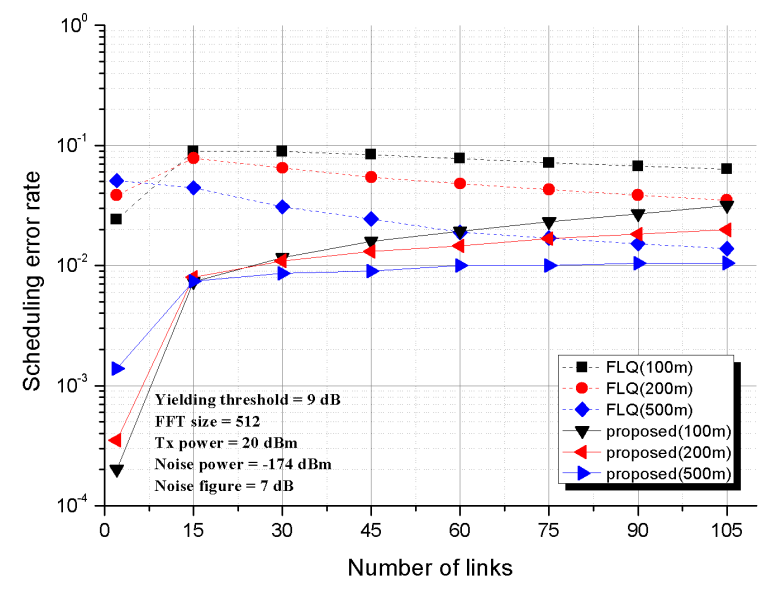

그림 7. 스케줄링 오류 성능 비교 (Threshold $=9 \mathrm{~dB}$ )

Fig. 7. Comparison of scheduling error rate (Threshold $=$ $9 \mathrm{~dB})$

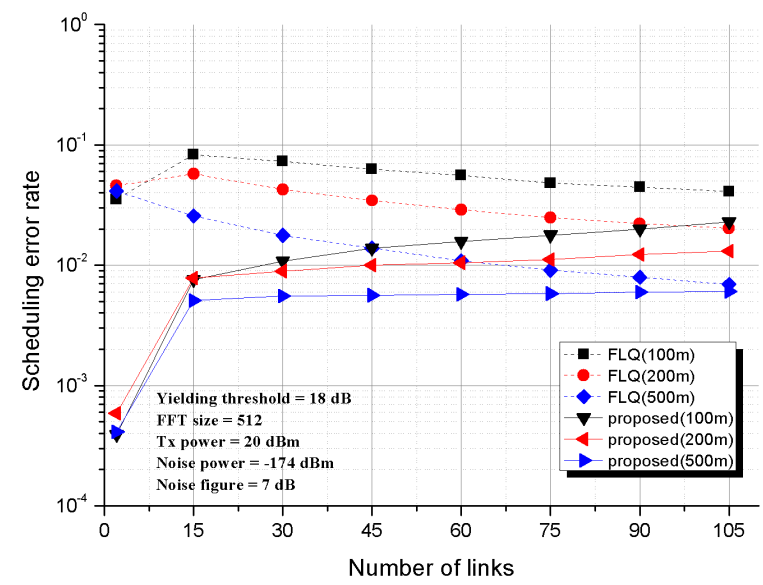

그림 8. 스케줄링 오류 성능 비교 (Threshold $=18 \mathrm{~dB}$ )

Fig. 8. Comparison of scheduling error rate (Threshold $=$ $18 \mathrm{~dB})$

한편, $\mathrm{Tx} / \mathrm{Rx}$-yielding 시 적용되는 SIR 임계치는 문헌 [3]에서 고려한 것과 동일한 $9 \mathrm{~dB}$ 및 $18 \mathrm{~dB}$ 를 적용하였다.

그림 7과 그림 8은 기존 기법과 제안 기법간 스 케줄링 오류율을 비교한 것으로 링크 수가 증가함 에 따라 스케줄링 오류율에 대한 기존 기법 대비 제안 기법의 성능 이득은 줄어드나, 임계치 $9 \mathrm{~dB}$ 및 $18 \mathrm{~dB}$ 모두에 대해 전반적인 성능 개선이 있음 을 확인 할 수 있다. 여기서 링크 수 증가에 따른 제안 기법의 스케줄링 오류율 이득 감소는 III.2절 에서 설명한 것과 같이, 링크 수가 증가함에 따라 sub-block 내 링크간 순환 오프셋 값의 중첩으로 인 한 SIR 측정 오차도 증가함을 의미한다. 하지만 제 안 기법의 경우, 최소 하나 이상의 sub-block에서의 전력 검출을 항상 보장하는 한편, $\mathrm{D} 2 \mathrm{D}$ 링크의 수 가 105 개에 달하는 경우에도 평균적으로 3 개 이상

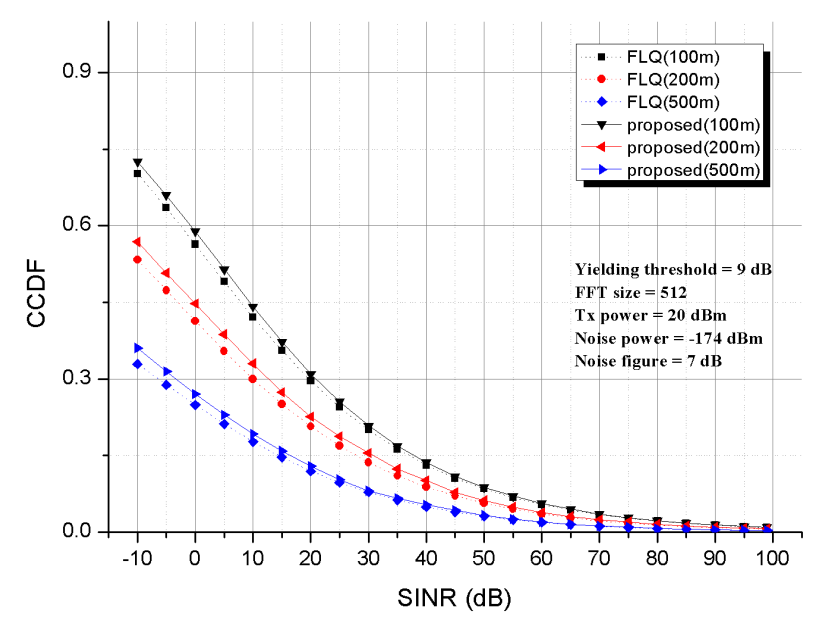

그림 9. 스케줄링된 링크들에 대한 SINR $\mathrm{CCDF}$ 비교 (Threshold $=9 \mathrm{~dB}, N=105$ )

Fig. 9. Comparison of SIR CCDF as the number of scheduled links changes (Threshold $=9 \mathrm{~dB}, N=105$ )

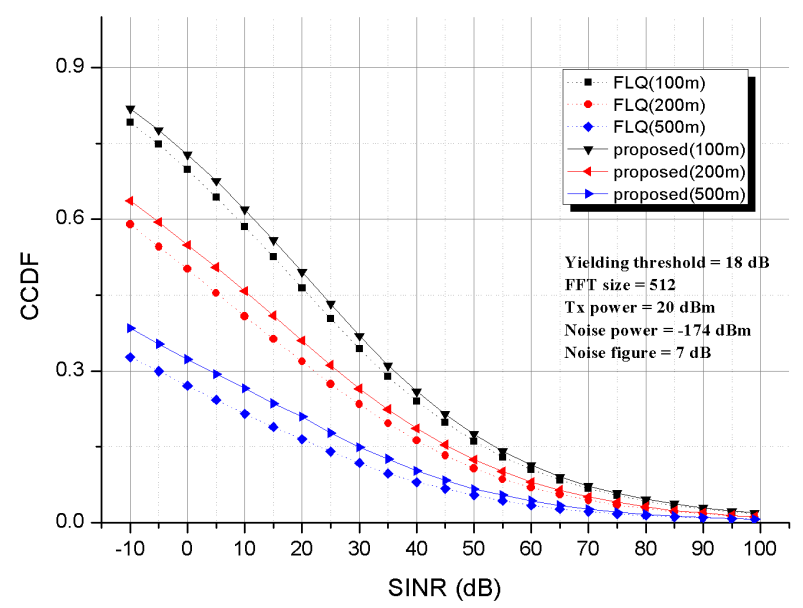

그림 10. 스케줄링된 링크들에 대한 SINR $\mathrm{CCDF}$ 비교 (Threshold $=18 \mathrm{~dB}, N=105$ )

Fig. 10. Comparison of SIR CCDF as the number of scheduled links changes $($ Threshold $=18 \mathrm{~dB}, N=105$ )

의 sub-block에서의 검출을 통한 평균 연산이 수행 됨으로 인해 상대적으로 정확한 수신 전력 측정이 가능하다. 제안 기법의 경우, sub-block 내 채널의 선택도로 인해 CAZAC 시퀀스간 간섭이 발생할 수 있으나, 매 sub-block 마다 서로 다른 순환 오프셋 값을 사용하기 때문에 인접 순환 오프셋 값을 사용 하는 시퀀스간 발생하는 간섭을 평균화할 수 있으 며, 또한 sub-block 내에서 시간/주파수 영역에서의 평탄 페이딩 조건을 만족하도록 sub-block 크기를 설정함으로써 추정 성능을 보장할 수 있다. 결과적 으로 기존 기법 대비 더 정확한 스케줄링 오류 성 능을 갖는 것을 확인할 수 있다.

그림 9 와 그림 10 은 $\mathrm{D} 2 \mathrm{D}$ 통신에 참여하는 단말 의 수 $N=105$ 일 때, 기존 기법 및 제안 기법의 


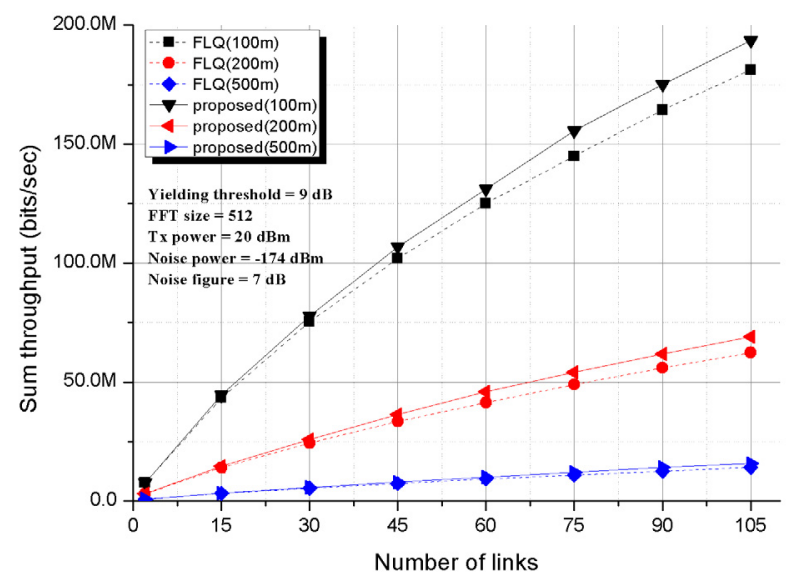

그림 11. 전체 전송률 성능 비교 $($ Threshold $=9 \mathrm{~dB}$ )

Fig. 11. Comparison of sum-throughput performance $($ Threshold $=9 \mathrm{~dB})$

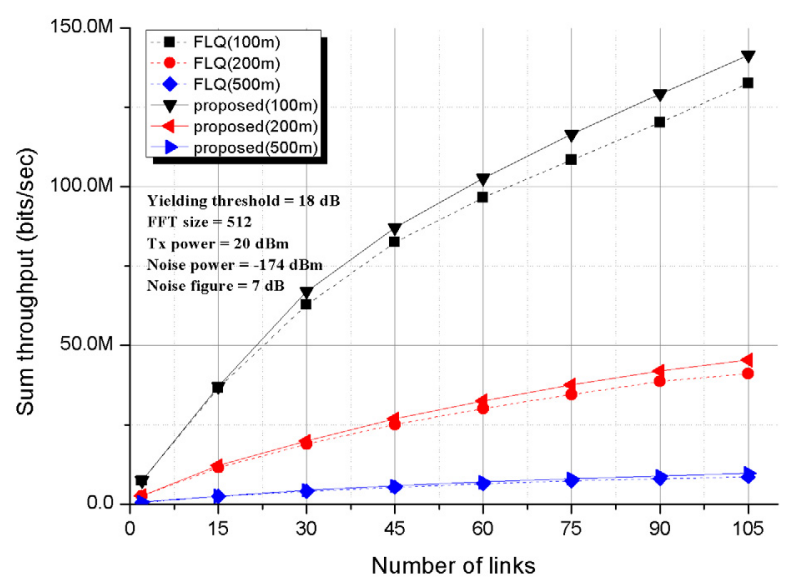

그림 12. 전체 전송률 성능 비교 (Threshold $=18 \mathrm{~dB}$ )

Fig. 12. Comparison of sum-throughput performance $($ Threshold $=18 \mathrm{~dB})$

스케줄링 된 링크들에 대한 SINR $\mathrm{CCDF}$ 를 나타낸 것으로, 제안 기법의 경우 기존 기법보다 스케줄링 링크들의 SINR 더 높은 값을 가지는 것을 확인할 수 있다. 이는 제안 기법 적용 시 스케줄링 오류율 이 감소함에 따라, 상위 링크에 큰 간섭을 일으키는 링크들이 보다 정확하게 yielding을 수행할 수 있기 때문이다. 즉, 잘못된 스케줄링으로 인해 타 링크에 게 큰 간섭을 주는 링크들이 생겨나 전체 링크의 간섭 상황을 악화시키는 기존 기법의 문제점이 개 선되었음을 의미한다. 한편, yielding 결정 시 사용 되는 SIR 임계치가 높을수록 SINR이 높은 링크들 만 살아남게 되므로 생존한 링크들의 평균 SINR이 높아지며, 이로 인해 그림 9 의 성능 대비 그림 10 의 $\mathrm{CCDF}$ 그래프가 오른쪽으로 치우치는 것을 확인 할 수 있다.

그림 11 과 그림 12 는 링크 수에 따른 전체 전송
률 성능을 비교한 것으로, 기존 기법 및 제안 기법 모두 SIR 임계치가 증가할수록 전체 전송률은 감소 하는 것을 확인할 수 있다. 이는 SIR 임계치가 높 을수록 간섭 상황이 매우 양호한 소수의 링크만 생 존함으로 인해 무선 자원의 재사용률이 낮아짐으로 인해 나타나는 결과이다. 또한, 그림 11 및 그림 12 의 결과를 통해 링크 수가 증가할수록 기존의 단일톤 구조 대비 제안 기법의 성능 이득은 증가함을 확인할 수 있는데, 이는 전체 링크 수가 증가할수록 yielding 수행 여부 판단 오류로 인해 다수의 링크 에 간섭을 일으키는 등, 스케줄링 오류로 인한 영향 이 증가하는 것을 의미한다. 모의 실험 결과, 105 개 의 링크 고려 시 제안 기법이 기존 기법 대비 임계 치 $9 \mathrm{~dB}$ 에서는 평균 $9 \%$, 임계치 $18 \mathrm{~dB}$ 에서는 평 균 $11.2 \%$ 내외의 전송률 이득을 가져 올 수 있음 을 확인할 수 있다.

이상의 분석으로부터, 제안 기법은 기존 기법 대 비 정확한 스케줄링을 수행함으로 인해 의도치 않 게 생존하여 다른 링크에게 간섭을 미치는 가해 링 크의 수를 줄일 수 있으며, 그로 인해 생존한 D2D 링크의 수신 SINR을 개선 가능함을 알 수 있다. 또 한, 생존 링크의 SINR 개선 효과로 인해 셀 전체에 대한 평균 전송률 측면에서 큰 폭의 이득을 얻을 수 있음을 확인할 수 있다.

\section{V. 결 론}

본 논문에서는 D2D 통신 시스템을 위한 새로운 분산형 링크 스케줄링 기법을 제안하였다. Qualcomm사의 FlashLinQ 시스템에서는 링크 스케 줄링 과정을 낮은 복잡도로 쉽게 실현하기 위해, 단 일-톤 기반의 통신 방식을 이용하여 각 링크들의 수 신 전력을 측정하는 구조를 제안하였으며, 이러한 신호 구조 하에서 각 링크의 SIR 및 우선순위에 기 반한 링크 스케줄링을 수행한다. 하지만 단일-톤 기 반의 링크 스케줄링 기술은 다중 경로 채널 환경에 서 주파수 선택적 페이딩에 의한 영향으로 단일-톤 위치에서의 수신 채널 전력과 전체 대역에 대한 수 신 채널 전력 간에 큰 차이가 발생할 수 있으며, 이러한 오차는 스케줄링 오류를 발생시키고 전체 전송률 성능을 열화시킬 수 있다. 본 논문에서는 이 러한 기존 기법의 문제점을 개선하기 위해 CAZAC 시퀀스의 상관 특성을 이용해 전체 대역에 대한 SIR 추정이 가능한 새로운 링크 스케줄링 기법을 고려하였다. 제안하는 구조에서는 각 링크의 송신단 
에서 전체 무선 자원을 다수의 sub-block으로 나누 어 sub-block 단위의 CAZAC 시퀀스를 전송한 후, 수신단에서 참조 신호와 수신 신호간의 순환 상호 상관 연산을 통해 간섭없이 링크간 SIR 값을 추정 할 수 있다. 다양한 컴퓨터 모의 실험 결과를 통해, 단일-톤 기반의 기존 링크 스케줄링 기법에 비해 제 안 기법이 향상된 스케줄링 오류율 및 전송률 성능 을 나타냄을 검증하였다.

\section{References}

[1] Y. J. Hwang, K. W. Sung, and S. L. Kim, "Feasibility of massive device-to-device communications in cellular networks," $J$. KICS, vol. 37, no. 12, pp. 1091-1101, Dec. 2012.

[2] K. Doppler, M. Rinne, C. Wijting, C. Ribeiro, and K. Hugl, "Device-to-device communication as an underlay to LTE-advanced networks," IEEE Commun. Mag., vol. 47, no. 12, pp. 42-49, Dec. 2009.

[3] X. Wu, S. Tavildar, S. Shakkottai, T. Richardson, J. Li, R. Laroia, and A. Jovicic, "FlashLinQ: A synchronous distributed scheduler for peer-to-peer ad hoc networks," in Proc. the 48th Annual Allerton Conf. commun., Control, and Computing, pp. 514-521, Monticello, U.S.A., Sep. 2010.

[4] Y. Wu, S. Attallah, and J. Bergmans, "Carrier frequency offset estimation for multi-user mimo-ofdm uplink using cazac sequences," in Proc. IEEE Wireless Commun. Networking Conf., pp. 1-5, Sydney, Australia, Apr. 2009.

[5] D. C. Chu, "Polyphase codes with good periodic correlation properties," IEEE Trans. Inform. Theory, vol. IT-18, no. 4, pp. 531-532, July 1972.

[6] J. Medbo and P. Schramm, "Channel models for HIPERLAN/2," ETSI/BRAN document, no. 3ERI085B, Mar. 1998.

[7] 3GPP, "Radio Frequency (RF) system scenarios," TR 36.942 V9.0.1, Apr. 2010.

\section{강 위 필 (Wipil Kang)}

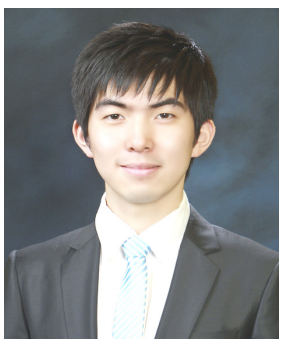

2012년 2월 성균관대학교 정 보 통신공학부 졸업

2012년 3월 현재 성균관대학 교 IT융합학과 석사 과정 <관심분야> 무선통신, 이동통 신, D2D 통신, 협력 통신 기술

\section{황 원 준 (Won-Jun Hwang)}

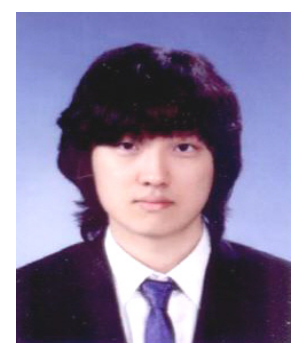

2009년 2월 성균관대학교 정보 통신공학부 졸업

2011년 2월 성균관대학교 전자 전기컴퓨터공학과 석사 2011년 3월 현재 성균관대학 교 IT융합학과 박사 과정 <관심분야> 무선통신, 이동통 신, $\mathrm{MIMO}$, 협력 통신 기술

\section{최 형 진 (Hyung-Jin Choi)}

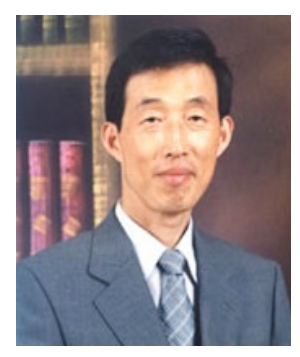

1974년 2월 서울대학교 전자공 학과 졸업

1976년 2월 한국과학기술원 전 기전자공학과 석사

1976년 3월 1979년 7월 (주)

금성사 중앙연구소 연구원 1979년 9월 1982년 12월 미

국 Univ. of Southern California 전기공학과 (공 학박사)

1982년 10월 1989년 2월 미국 Lincom Corp.연구 원

1989년 3월 현재 성균관대학교 정보통신대학 교수 <관심분야> 디지털통신, 무선통신, 이동통신, 위성 통신 및 동기화 기술을 포함한 MODEM 기술 